\begin{tabular}{|c|c|c|}
\hline \multirow{2}{*}{8} & $\begin{array}{l}\text { International Journal of Current Research in } \\
\text { Biosciences and Plant Biology }\end{array}$ & $=$ \\
\hline & Volume $5 \bullet$ Number 2 (February-2018)・ISSN: 2349-8080 (Online) & \\
\hline $\begin{array}{l}\text { EXCELLENT } \\
\text { PUBLISHERS }\end{array}$ & Journal homepage: www.ijcrbp.com & \\
\hline
\end{tabular}

\title{
Study of the Physical and Structural Properties of Some Local Mineral Clays and Effect of Doping with Chromium Oxide
}

\author{
Regab. A. Buker and Zena. M. Shaban* \\ Department of Chemistry, College of Education, Mosul University, Iraq \\ *Corresponding author.
}

\begin{tabular}{ll}
\hline Article Info & A BS TRA C T \\
\hline $\begin{array}{l}\text { Date of Acceptance: } \\
\text { 12 January 2018 }\end{array}$ & $\begin{array}{l}\text { Chemical composition, physical properties and structural characterization of local } \\
\text { natural mineral clays have been studied. The study approach is based on using X-ray } \\
\text { diffraction and fluorescence, thermal gravimetric analysis, differential scanning }\end{array}$ \\
$\begin{array}{l}\text { Date of Publication: } \\
\text { 06 February 2018 }\end{array}$ & $\begin{array}{l}\text { calorimetry, infrared spectroscopy, instrumental and classical chemical analysis } \\
\text { techniques. The results were compared with those obtained from acidically treated and } \\
\text { chromium oxide doped clay samples. Four samples were prepared in order to be a } \\
\text { Keyw ords }\end{array}$ \\
$\begin{array}{l}\text { more active and selective adsorbent materials. Soxhlet fractionating techniques were } \\
\text { set for all the above types of adsorbents using four eluants gradually increased in } \\
\text { Soxhlet extraction } \\
\text { Virgin olive oil }\end{array}$ & $\begin{array}{l}\text { polarity. The fractionation results showed significant variations in the fractions isolated } \\
\text { according to their polarities as indicated by percentage results. }\end{array}$ \\
\hline
\end{tabular}

\section{Introduction}

Many types of mineral clays, which are natural resources, located in massive deposits around the Governorates of Nineveh ${ }^{[1]}$. Such mineral clays have not been utilized yet, inspite of their possibility usage as catalysts in industry in general and especially in fractionation processes. This consideration arises from the fact that such materials accompanied in their locations with heavy crude oil resources as well as local virgin olive oil ${ }^{[2,3]}$. The demand for all kinds of naturally sources of foods and drugs such as olive oil have been the subject for many workers ${ }^{[4-6]}$. Such materials contain a mixture of complex hydrocarbon compounds that can easily be separated by fractionation processes to their major components which are triglycerides and other minor components phenolic and volatile compounds such as aldehydes ${ }^{[3]}$.

Meanwhile, locally mineral clays and their manufactured compounds are proposed to be good adsorbents and catalysts in the above refining processes. Recently, Buker and Taher applied ninevite silica gel doped with chromium oxide in solid phase extraction to separate Iraqi virgin olive oil into their simple components ${ }^{[3]}$.

As a continuation of these studies very recent investigations were reported applying some local ninevites doped with some complexes in order to be 
more active and selective adsorbent material in chromatographic columns ${ }^{[7]}$.

The present study covers an investigation into the application of Aski-Mosul (a suburb of the Governorate of Nineveh) mineral clays after acidic and basic treating and doping them with chromium oxide in Soxhlet technique. They have to be employed as a catalyst in adsorption chromatography to fractionate some Iraqi virgin olive oils.

\section{Materials and methods}

\section{Source, collection and preparation of samples}

Natural clay samples were collected from Aski Mosul village, area around Mosul city/ Iraq. These samples are bearing some scemitite mineral clays in addition to silica and other non-mineral clays ${ }^{[8]}$. The solubility of the clay samples in both the acidic and basic medium was studied and the treated samples as well as the natural one were doped by chromium oxide, $\mathrm{Cr}_{2} \mathrm{O}_{3}$, applying the impregnation methods ${ }^{[9]}$ to prepare four samples. $\mathrm{Cr}_{2} \mathrm{O}_{3}$ was mixed with clay samples in a ratio 1:8 mole respectively, stirred with distilled water and small amount of ethanol for several hours, filtered, dried at $110^{\circ} \mathrm{C}$, and heated at $260^{\circ} \mathrm{C}$ for $2 \mathrm{hrs}$. All samples were physically studied using several techniques including powder $\mathrm{x}$-ray diffraction, thermal gravimetric analysis, differential scanning calorimetry, and infrared spectroscopy, in order to obtain active and selective adsorption material. Moreover, those samples were chemically formulated following several chemical analysis methods ${ }^{[10]}$ in addition to $\mathrm{X}$-ray fluorescence technique.

\section{X-ray powder diffraction and fluorescence}

Powder x-ray diffraction studies were carried out using $\mathrm{Cu} \mathrm{k} \alpha$ radiation and diffraction patterns were recorded using Shimadzu X-ray Diffraction 7000, 2009 , fitted with a vertical goniometry. The phase contributing to the x-ray diffraction patterns were identified by reference to the Joint Committee on
Powder Diffraction Standers Powder Diffraction File. Meanwhile, X-ray fluorescence data were obtained using Oxford, X-MET 7500 fluorescence analyzer.

\section{Thermal analysis}

Thermogravimetric analysis and differential scanning calorimetry were recorded between 25 and $380^{\circ} \mathrm{C}$ on METTLER TOLEDO, TGA/ DSC $\mathrm{STAR}^{\mathrm{e}} \mathrm{SW} 9.30$ thermal analysis. The heating rate was $5^{\circ} \mathrm{C}$ min $^{-1}$ and $\alpha-\mathrm{Al}_{2} \mathrm{O}_{3}$ was used as standard reference. The measurement was carried out in ALAl-Bait University/ Jourdan Kingdom.

\section{Infrared Spectra}

The absorption spectra of samples under investigation were recorded on SHIMADZO, IR Affinity-1 spectrophotometer using $\mathrm{KBr}$ pellets and $\mathrm{NaCl}$ cell ${ }^{[11]}$.

\section{Application}

Four adsorption fractionating Soxhlet techniques were prepared which were packed applying natural, treated, natural and doped and treated and doped clay samples as adsorbent materials. All samples were of chromatographic grade (300-425 $\mu_{\mathrm{m}}$ ) and activated to be employed in the processes.

A known weight $(2 \mathrm{~g})$ of Iraqi virgin olive oil was fractionated into four isolated samples according to their adsorption polarities using four eluants of different polarities which are petroleum ether, toluene, chloroform and ethanol. IR, ${ }^{1} \mathrm{H}$ NMR, GCMS investigation will be presented in future article very soon ${ }^{[12]}$ in order to study the chemical composition of the eluted stuff and to evaluated the adsorption activity and selectivity of the investigated samples.

\section{Results and discussion}

\section{Physical and chemical characterization}

Physical properties (e.g. density, porosity, water 
absorption, pore size and capillary action) have been measured following the methods described in the literature ${ }^{[13]}$. Table 1 shows such data related to the four clay samples under investigation. The capillary action, Fig. 1 revealed the rising of water level as monitored with time is taken as the measurement of this action. It is clear that physical properties of these samples show notable difference. It seems that the treated clay sample has low density and high porosity and permeability. Moreover, the doped samples are more dens than others. Such variation because of the elimination of carbonate compounds on treating and doping processes. Meanwhile, the low capillary action at natural sample on comparison with the rest samples may explain the fact that natural clay sample contain large number of small pores which are well connected by an extremely narrow channels ${ }^{[2]}$. Furthermore, it seems that doping with chromium oxide affects creating much more permeable new catalysts with different physical properties. As a result, it looks that treating and doping clay samples appeared to be generally the best, regarding adsorption activity ${ }^{[14]}$.

Table 1. Physical properties of clay samples.

\begin{tabular}{llllll}
\hline Sample & $\begin{array}{l}\text { Density } \\
\mathbf{g} / \mathbf{c m}^{\mathbf{3}}\end{array}$ & $\begin{array}{l}\text { Porosity } \\
\mathbf{\%}\end{array}$ & $\begin{array}{l}\text { Pore size } \\
\mathbf{c m}^{\mathbf{3}} \mathbf{g}\end{array}$ & Water absorption $\mathbf{\%}$ & $\mathbf{p H}$ \\
\hline Natural & 2.3 & 31.16 & 1.87 & 154 & 8.1 \\
Treated & 2.14 & 36.5 & 2.19 & 76.4 & 4.95 \\
Doped natural & 2.1 & 47 & 2.82 & 225 & 7.8 \\
Doped treated & 1.8 & 50.5 & 3.03 & 238 & 6.3 \\
\hline
\end{tabular}

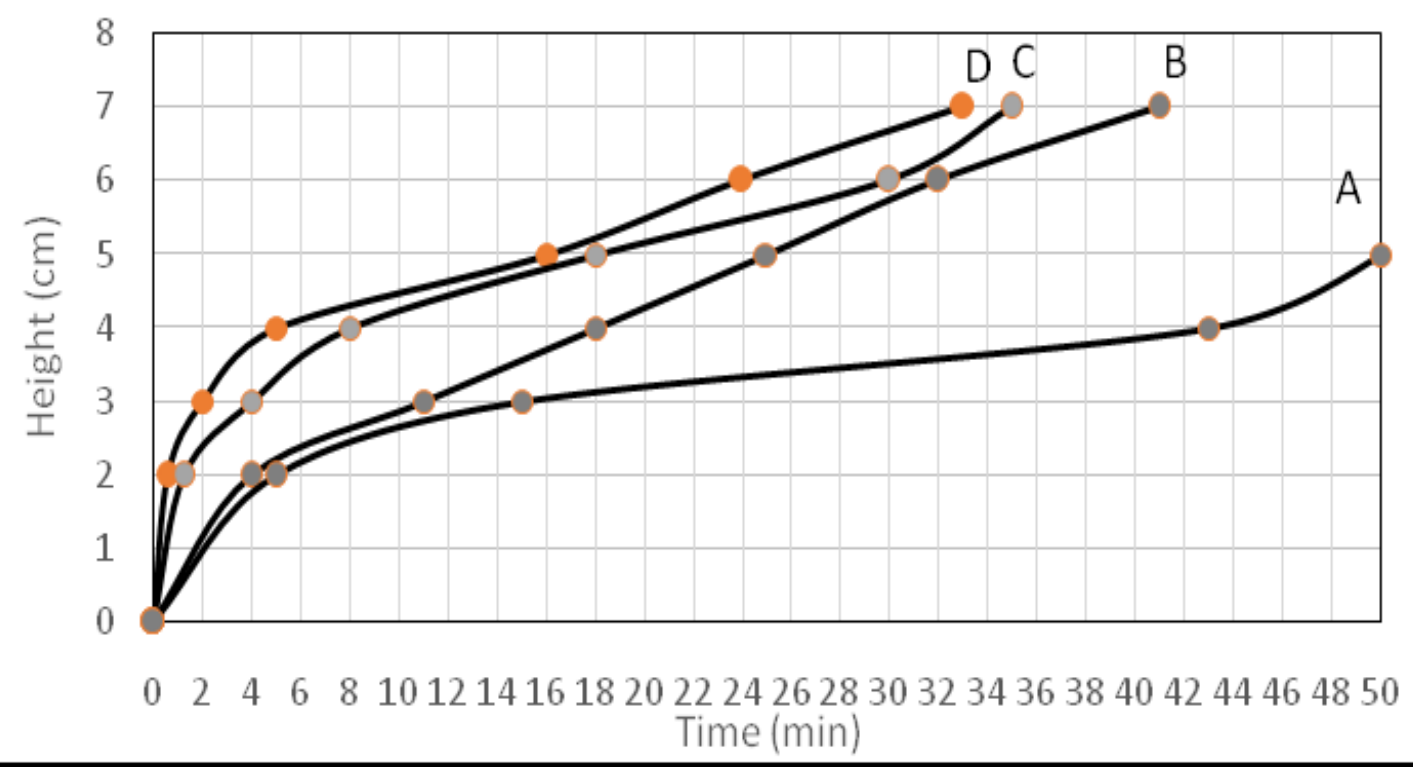

Fig. 1: Capillary action curves of (A) natural clay (B) treated clay (C) doped natural clay (D) doped treated clay sample.

X-ray fluorescence and instrumental chemical analyses such as atomic absorption and flam photometry, have been used to study the chemical composition of the four clay samples under investigation and the data of these analyses are shown in Table 2. It is clear that natural sample contain large amounts of silica and calcium oxide in addition to aluminum oxide and other minor oxides. Moreover, it is shown that such sample yields (5\%) amorphous silica on treating with basic medium ${ }^{[7]}$. On the other hand, the treated sample data reflect the less values of carbonate compounds because of 
the elimination processes. On doping of those samples, the results of analysis however, improve the doping factor molar ratio 1:8 of chromium to clay material.

\section{Structural studies}

Rocks and mineral clays occurred naturally and there is a difficulty in finding a sample consisting $100 \%$ of a single phase compound. Therefore, the natural mineral clay samples indeed compose of so many other minor compounds in addition to the primitive one which is for example smectite mineral clay. Carful x-ray powder diffraction studies reveal the presence of these mixed layer structures and frequently indicate their nature and relative abundance ${ }^{[15]}$.

Accordingly, x-ray powder diffraction for natural clay sample was carried out. Fig. 2 shows the sample pattern which contains reflections typical to quartz in addition to montmorillonite, illite and kaolinite. The amorphous silica may also be defined as abroad hump between $2 \theta$ (18-22). However, the interplanar spacings of the all contributing phases might be presented in Table 3 .

Table 2. Chemical composition of clay samples.

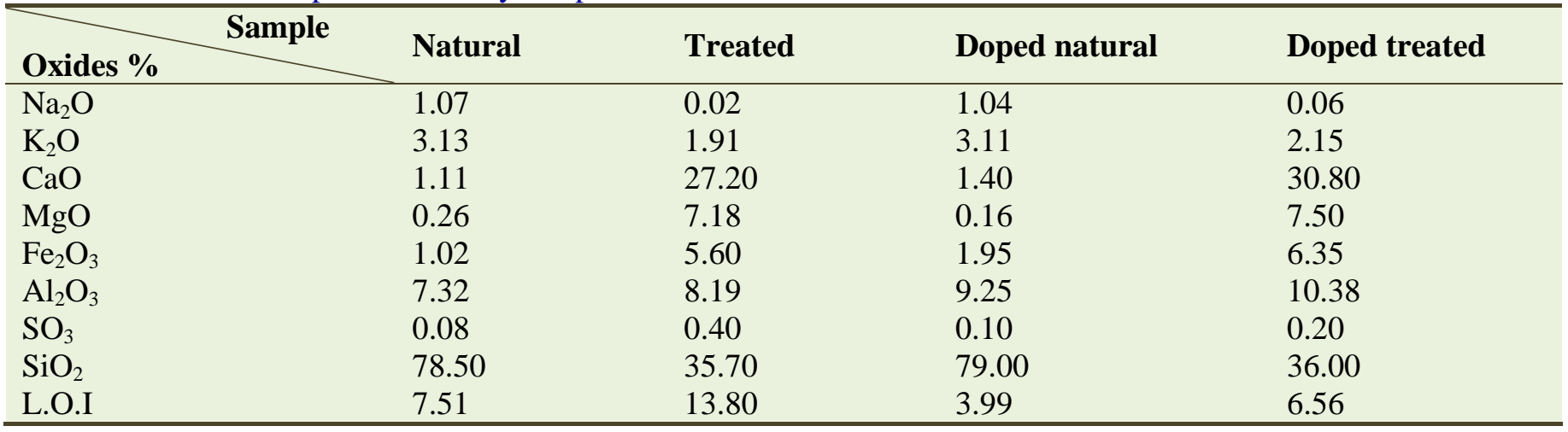



Fig. 2: Powder X-ray diffraction pattern of natural clay sample. 
Table 3. Interplanar spacings of contributing phases in natural clay sample.

\begin{tabular}{llll}
\hline Crystalline phase & $\mathbf{2 \theta}$ & $\mathbf{d}$-spacing $\mathbf{A}^{\mathbf{0}} \mathbf{)}$ & $\mathbf{h k l}$ \\
\hline Montmorillonite & 6.1 & 14.47 & 001 \\
Montmorillonite & 19.8 & 4.48 & 110 \\
Montmorillonite & 27.7 & 3.02 & 005 \\
Montmorillonite & 36.5 & 2.50 & 200 \\
Illite & 8.7 & 10.2 & 002 \\
Illite & 17.8 & 5.03 & 004 \\
Illite & 22.9 & 3.88 & 113 \\
Illite & 45.6 & 1.99 & 010 \\
Kaolinite & 12.4 & 7.13 & 001 \\
Kaolinite & 21.1 & 4.18 & 111 \\
Kaolinite & 35.1 & 2.57 & 201 \\
Kaolinite & 38.5 & 2.34 & 202 \\
Quartz & 20.9 & 4.26 & 100 \\
Quartz & 26.6 & 3.34 & 101 \\
Quartz & 39.4 & 2.28 & 102 \\
Quartz & 49 & 1.82 & 112 \\
Calcite & 29.4 & 3.03 & 104 \\
Calcite & 36 & 2.49 & 110 \\
Calcite & 43.1 & 2.09 & 202 \\
Calcite & 47.5 & 1.91 & 018 \\
Dolomite & 31 & 2.89 & 104 \\
Dolomite & 37.5 & 2.40 & 110 \\
Dolomite & 41.1 & 2.19 & 113 \\
Dolomite & 44.9 & 2.02 & 202 \\
Hematite & 24.3 & 3.66 & 012 \\
Hematite & 33.4 & 2.69 & 104 \\
Hematite & 43.9 & 2.08 & 202 \\
Hematite & 49.5 & 1.84 & 024 \\
\hline & & & \\
\hline
\end{tabular}

On treating the clay sample and doping with chromium oxide followed by calcination at $700^{\circ} \mathrm{C}$, it seem that good crystalline phases were obtained. Furthermore, it looks that calcite and dolomite compounds were eliminated in addition to the destruction of montmorillonite and kaolinite crystal structures. X-ray diffraction chart of these samples are modified to the data presented in Table 4. This presentation clearly indicates the interplanar spacing of the contributing phases present in the above sample. Therefore, all samples under investigation were avoided from heating above $260^{\circ} \mathrm{C}$ to be active adsorbents whenever they were employed.

The aim of the present study is to prepare a modified mineral clay samples which contain the doped chromium oxide. Such goal to be achieved differential scanning calorimetry technique might be employed, followed by thermogravimetric degradation in order to obtain an activated catalyst. Fig. 3 shows DSC curve of chromium doped natural clay sample which contains three endothermic peaks representing the three types of hydration water molecules. The first at $90^{\circ} \mathrm{C}$ related to the free water molecules on the surface and between the intermolecular planar of the clay. While the second one at $160^{\circ} \mathrm{C}$ corresponded to the water molecular which are connected to the clay via hydrogen bonding. Finally, the third peak represents the type of molecules which are coordinated to the clay sample ${ }^{[16]}$. Meanwhile, DSC curves of the rest of samples were noted to be similar to the above one except in a small variation in the position of the hydration peaks. 
To interpret such foundation, TGA of the investigated samples were performed and Fig. 4 represents one of such analysis. It is clear that losses of 54, 19 and $27 \%$ of the whole water molecules weight were observed which correspond to the dehydration phenomena ${ }^{[17]}$.

Table 4. Interplanar spacings of contributing phases in doped treated clay sample.

\begin{tabular}{llll}
\hline Crystalline phase & $\mathbf{2 \theta}$ & $\mathbf{d}$-spacing $\mathbf{A A}^{\mathbf{0}} \mathbf{~}$ & $\mathbf{h k l}$ \\
\hline Montmorillonite & 6.3 & 13.94 & 001 \\
Montmorillonite & 19.8 & 4.48 & 110 \\
Montmorillonite & 27.7 & 3.02 & 005 \\
Montmorillonite & 34.7 & 2.58 & 200 \\
Illite & 8.7 & 10.2 & 002 \\
Illite & 17.8 & 5.03 & 004 \\
Illite & 22.9 & 3.88 & 113 \\
Illite & 45.6 & 1.99 & 010 \\
Quartz & 20.9 & 4.26 & 100 \\
Quartz & 26.6 & 3.34 & 101 \\
Quartz & 36.2 & 2.48 & 110 \\
Quartz & 42.3 & 2.13 & 200 \\
Chromatite & 24.4 & 3.64 & 012 \\
Chromatite & 33.6 & 2.67 & 104 \\
Chromatite & 39.4 & 2.28 & 006 \\
Chromatite & 41.4 & 2.17 & 113 \\
Calcite & 29.4 & 3.03 & 104 \\
Calcite & 43.1 & 2.09 & 202 \\
Calcite & 47.5 & 1.91 & 018 \\
Calcite & 49.2 & 1.87 & 116 \\
Dolomite & 24.1 & 3.69 & 012 \\
Dolomite & 31 & 2.89 & 104 \\
Dolomite & 37.5 & 2.40 & 110 \\
Dolomite & 44.1 & 2.06 & 021 \\
\hline
\end{tabular}

Table 5. Soxhlet extractions (\%) of $2 \mathrm{~g}$ Iraqi virgin olive oil using different adsorbents.

\begin{tabular}{|c|c|c|c|c|c|}
\hline \multirow[b]{2}{*}{ Sample } & \multicolumn{4}{|l|}{ Solvents } & \multirow[b]{2}{*}{ Loss \% } \\
\hline & $\begin{array}{l}\text { Petroleum ether } \\
0.0\end{array}$ & $\begin{array}{l}\text { Toluene } \\
\mathbf{2 . 3 8}\end{array}$ & $\begin{array}{l}\text { Chloroform } \\
4.81\end{array}$ & $\begin{array}{l}\text { Ethanol } \\
24.6\end{array}$ & \\
\hline Natural & 70 & 14.5 & 3 & 3.5 & 9 \\
\hline Treated & 64.5 & 24.5 & 4 & 4.5 & 2.5 \\
\hline Doped natural & 77.5 & 18 & 1.5 & 2.5 & 0.5 \\
\hline Doped treated & 79 & 15 & 2 & 3 & 1 \\
\hline
\end{tabular}

Finally, it is of interest to study the migration and elimination of the above water molecules from clay samples on increasing the temperature, in addition to the clay mineralogy by infrared spectroscopy. Therefore, a range of $400-4000 \mathrm{~cm}^{-1}$ in frequency was applied and the spectra show several absorption bands including those between 1024$1093 \mathrm{~cm}^{-1}$ which may be attributed to the (Si-O) stretching vibration ${ }^{[18]}$. Also there are absorption bands at 796-694 $\mathrm{cm}^{-1}$ which are related to $\mathrm{Si}-\mathrm{O}-\mathrm{M}$ groups, and those at 877,468 which correspond to $\mathrm{Al}-\mathrm{O}$ and Fe-O respectively. Finally, the bands at $3618-3546 \mathrm{~cm}^{-1}$ and at 1456-1431 $\mathrm{cm}^{-1}$ which represent the structural $\mathrm{OH}$ groups and $\mathrm{CO}_{3}{ }^{-2}$ respectively. Such absorptions show a significant variation in the position and sharpness of the 
vibrations upon treating and heating the samples in the range of $90-500^{\circ} \mathrm{C}$. This may be related to the elimination of carbonate compounds and the dehydration phenomenon.

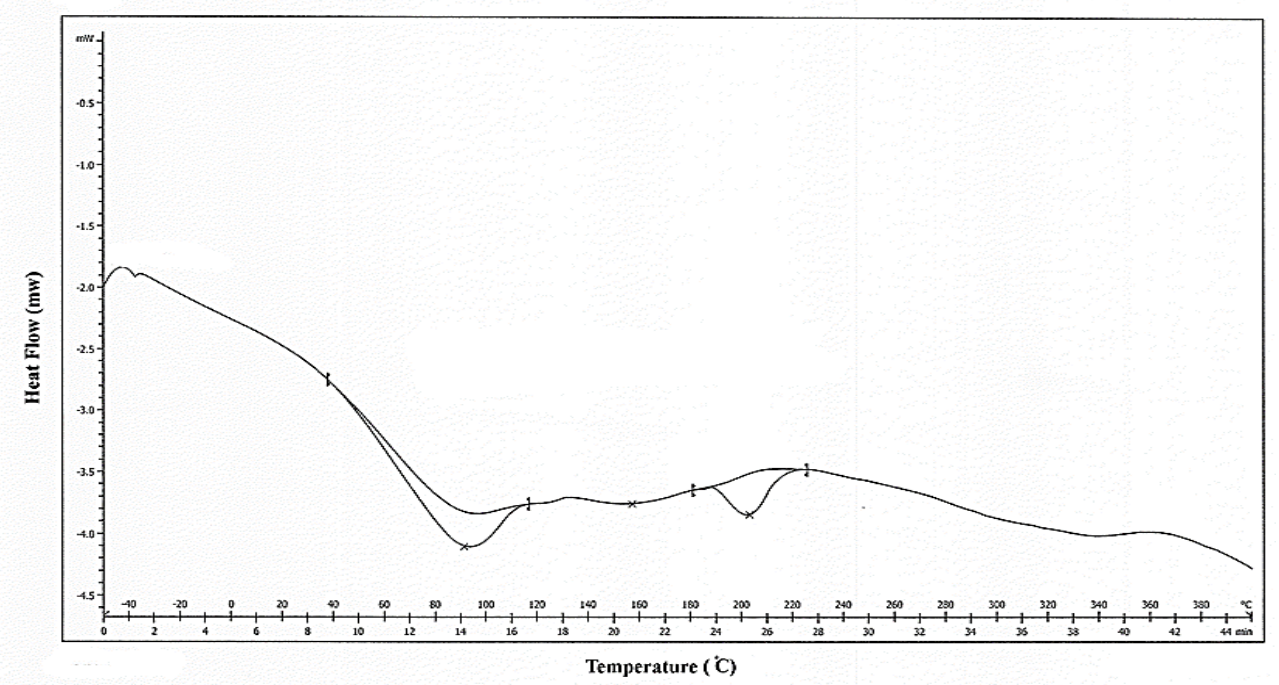

Fig. 3: Differential scanning calorimetry curve of chromium doped clay sample.

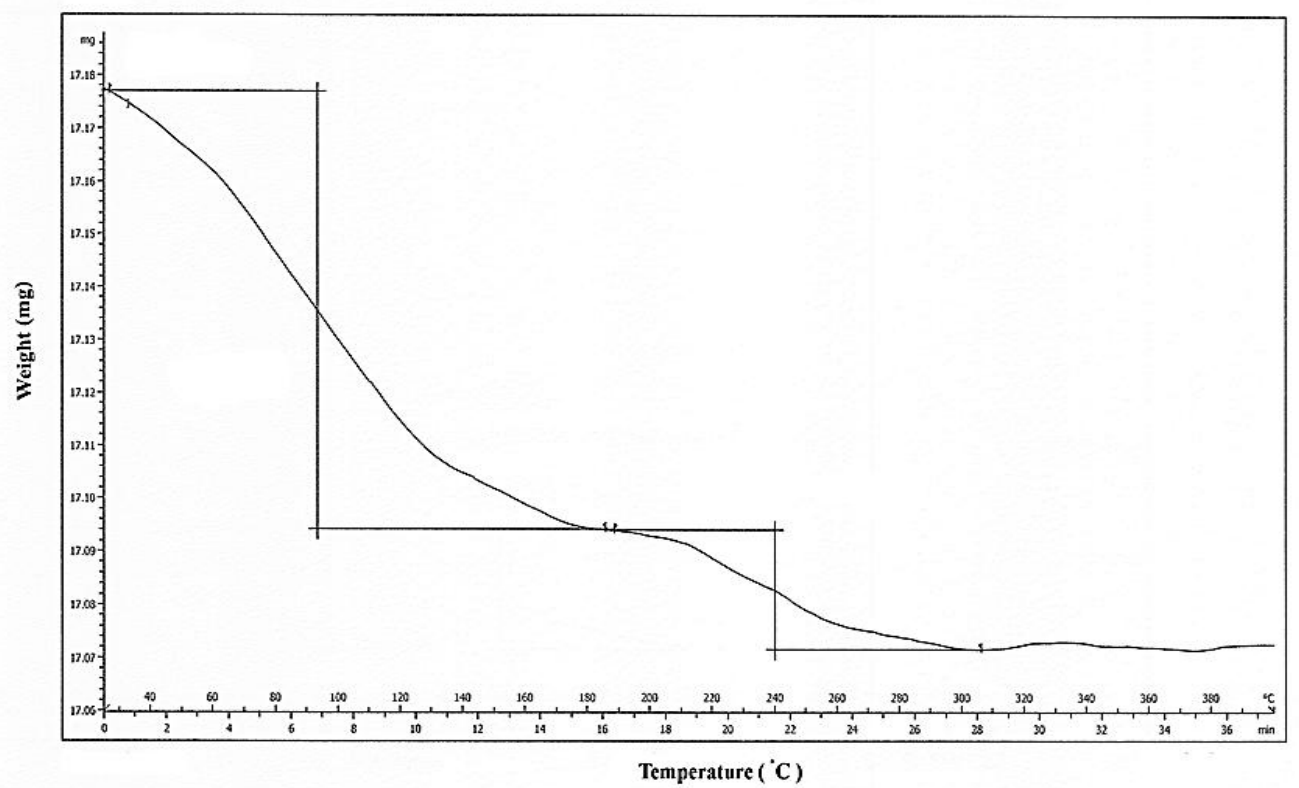

Fig. 4: Thermogravimetric analysis curve of chromium doped clay sample.

\section{Soxhlet extraction of Iraqi virgin olive oil components}

The above results obtained for four clay samples in the present study show a significant variation in their chemical composition, physical properties, and especially in their structural components. It is therefore, of interest to get benefit of such findings in evaluating the studied clay samples in order to be applied as good adsorbents in fractionation processes. The clay samples are suitable for the separation of majority of substances or for the separation of complex mixtures into groups of compounds.

Accordingly, four fractionating Soxhlets were packed with the chromatographic grade (425- 
$300 \mu_{\mathrm{m}}$ ), already activated at $260^{\circ} \mathrm{C}$, clay samples. They were employed to extract Iraqi virgin olive oil using four eluants increased gradually in their polarities. The oil samples were fractionated into four chemically simple components according to their polarities which created upon using, petroleum ether, toluene, chloroform, and ethanol solvents. The results of such separation are presented in Table 5. The results revealed the percentages of the fractions eluted according to their adsorption polarities.

In general, it is clear that adsorption and desorption of olive oil materials on clay samples has strongly occurred and as a result separated into four components. However, on referring to the previous studies in this field ${ }^{[2,3,7]}$. It seems that the best separation and fractionation occurred in case of using the treated clay sample. This suggestion depends on the values of fractions percentage, therefore, to prove such proposed results more investigation was needed. For example chemical characteristic nature of the eluted fractions should be studied via IR, ${ }^{1} \mathrm{H}$ NMR and GC-MS techniques and it will be hopefully presented very soon in a future article ${ }^{[12]}$.

\section{Conflict of interest statement}

Authors declare that they have no conflict of interest.

\section{References}

1- M. Dahbia, Al-Muchtuma Al-Arabi publishing company, Amman, Jorden. pp. 173, (2006).

2- R. Buker and S. Al-Mallah, J. Edu. Sci., Vol. 17, No. 4, pp. 42-53, (2005).

3- R. Buker and N. Taher, Dirasat, Pure Sciences,
Vol. 33, No. 2, pp. 158-167, (2006).

4- J. Quiles, M. Carmen and P. Yaqoob, CAB International, London, UK, pp. 46, 49,51, (2006).

5- A. Koidis and D. Boskou, Eur. J. Lipid Sci. Technol. Vol. 108,pp. 323-328, (2006).

6- C. Lazzerini and V. Domenici, Journal of Foods, Vol. 6, No. 25, pp. 1-11, (2017).

7- R. Buker and A. Al-Botani, J. Raf. Sci., Vol. 20, No. 2, pp. 52-64, (2009).

8- A. Meunier, "Clays", Springer-Verlag, Germany, pp. 1,9,11, (2005).

9- J. Anderson and M. Garcia, "Supported Metals in Catalysis", $2^{\text {nd }}$. Ed., Imperial College Press, London, UK, p. 4, (2012).

10- P. Jeefery and D. Hutchison, "Chemical Methods of Rock Analysis", $3^{\text {rd }}$.Ed., Peregamon Press, New York, pp. 18-22, 30-39, 222, (1981).

11- B. Schrader, "Infrared and Raman Spectroscopy", VCH, Inc., New York, USA, p. 224, (1995).

12- R. Buker, S. Ahmad and Z. Shaban, (to be published in 2018).

13- J. Kozel, "Text Book on Density and Porosity of Rocks", Academic Press, New York, USA, pp.155-170, (1975).

14- R. Vartak, Resonance, Vol. 6, No. 5, pp. 83-91, (2001).

15- C. Klein, "Mineral Science", $22^{\text {nd }}$. Ed., John Wily and Sons, Inc., USA, P. 407, (2002).

16- F. Wypych and K. Satyanaryana, "Clay Surfaces: Fundamentals and Applications", Elsevier Ltd., p. 10, (2004).

17- P. Stazczuk, Thermochimica Acta, Vol. 308, No. 1, pp. 147-157, (1998).

18- B. Tyagi, C. Chudasama and R. Jasra, Spectrochimica Acta Part A, Vol. 64, pp. 273278, (2006).

\section{How to cite this article:}

Buker, R. A., Shaban, Z. M., 2018. Study of the physical and structural properties of some local mineral clays and effect of doping with chromium oxide. Int. J. Curr. Res. Biosci. Plant Biol. 5(2), 18-25. doi: https://doi.org/10.20546/ijcrbp.2018.502.003 